\title{
Evaluation of the cavitation generator efficiency in the hydro impulsive loosening of a coal-bed
}

\author{
Vasyl Zberovskyi ${ }^{1,}$, Yurii Zhulai ${ }^{1}$, and Serhii Mirnyi ${ }^{2}$ \\ ${ }^{1}$ Institute of Geotechnical Mechanics named by N. Poljakov of National Academy of Sciences of \\ Ukraine, 49005, Dnipro, Simferopolska Str., 2a, Ukraine \\ ${ }^{2}$ Institute of Transport Systems and Technologies of National Academy of Sciences of Ukraine, \\ 49005, Dnipro, Pisarzhevskoho Str., 5, Ukraine
}

\begin{abstract}
The paper presents the results of mining and experimental work, bench tests and theoretical studies of the energy characteristics of the stationary and pulsating fluid flow, which allow to estimate the efficiency of the cavitation generator in the hydro impulsive loosening of an outburstprone coal-bed. The active stage of the hydro impulsive loosening and the effective range of the amplitude-frequency (AF) spectrum of the generator operation acoustic signal have been established by the AF spectrum of the sound accompaniment of the hydro impulse impact and the backup pressure of the liquid in the well. By calculation for this range the energy characteristics of the static and dynamic components of the pulsating fluid flow were determined. This made it possible to determine that the efficiency of the cavitation generator, all other conditions of the coal-bed hydro loosening being equal, is 4.8-1.2 times higher than the efficiency of the static impact.
\end{abstract}

\section{Introduction}

It is known that the imposition of dynamic loads on the block-layered structure of a coalbed increases the speed and quality of its hydro loosening. In the Institute of Geotechnical Mechanics named by N. Poljakov of National Academy of Sciences of Ukraine it was developed promising device for hydro impulsive impact on the coal-bed [1]. The device is created based on the standard sealer of the well "Taurus".

The generator of cavitational self-oscillations (hereinafter the generator) is installed in the tip of the sealer. This made it possible to eliminate energy losses and transfer the dynamic load to the coal-bed directly in the filtration section of the well.

The generator is the Venturi tube of special geometry in the flow part of which highfrequency self-oscillations of fluid pressure occur $[2,3]$. In the filtration section of the well, the energy of the cavitational oscillations of liquid medium is transformed into the energy of a hydro-impulse vibration. High-frequency impact of power pulses on the block-layered structure of the coal-bed leads to its fatigue state. Therefore, even at medium stresses that do not reach the strength of coal [4], a multidirectional network of microcracks develops and it is occurred the discontinuity in the coal-bed.

The indisputable advantage of this device, in contrast to the known mechanisms and

*Corresponding author: avalansh@ua.fm 
methods [5-7], is the absence of additional energy sources and moving mechanical parts. The generator is located in the well and all the energy of cavitation self-oscillations is spent on the hydro impulsive loosening of the bed. When it is conducted the mining operations at threatened and dangerous beds by sudden coal and gas emissions, the "Rules ..." [8] defines the requirements for forecasting and controlling the danger of coal-bed for gas-dynamic phenomena (GDP). In order to control the dynamic parameters and evaluate the effectiveness of the new method of hydroimpulsive loosening [9], based on standard methods [8], new methods were developed to monitor the state of the coal bed and control the hydroimpulsive effect. The developed methods make it possible to control the process of hydro-loosening, but do not allow to estimate the effectiveness of the device operation. Therefore, the purpose of this work is to determine the efficiency of the device and evaluate its effectiveness.

To achieve this goal, it was used the results of mining and experimental works, the results of bench tests of the device for hydro impulsive impact on the coal bed, theoretical studies of the energy characteristics of stationary and pulsating fluid flow.

\section{Validation of the range for research}

The basis of our research will take the results of mining and experimental works at the pressure of the fluid at the generators inlet $P_{\mathrm{n}}=11 \mathrm{MPa}$.

In Figure 1 it is shown the amplitude-frequency (AF) spectrum of the sound of a hydroimpulsive loosening of a coal bed, recorded by the ZUA-98 equipment $[10,11]$.

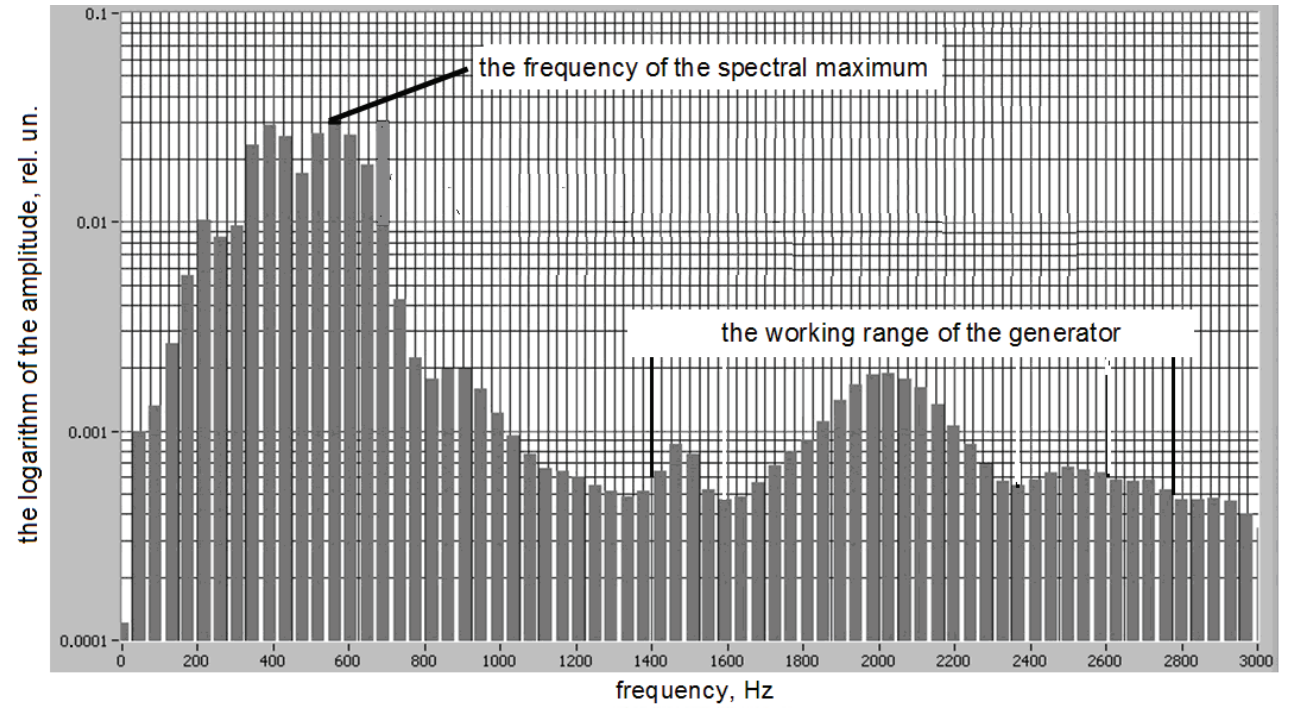

Fig. 1. Amplitude-frequency spectrum of sound accompaniment of hydro-impulsive loosening of coal bed (copy from operator's monitor).

The seismogram reflects the intensity of acoustic emission (AE) of the signal in the frequency range from zero to $3.0 \mathrm{kHz}$. The soundtrack spectrum of $\mathrm{AE}$ characterizes its energy at different intensity of the process. In our example, the range of low-frequency vibrations of $100-150 \mathrm{~Hz}$ is associated with electrical noise. Part of the energy of highfrequency oscillations of $200-800 \mathrm{~Hz}$ is associated with the process of fluid filtration and the development of cracks around the well, and some with ultrasonic vibrations of the coal bed.

The high-frequency region of the spectrum is associated with pressure pulses, which are 
realized by the device generator. If there are no high-frequency components in the AF spectrum with a high level of energy of the sound impulse of a hydro-impulse effect, then the generator operates without load, i.e. hydro impulsive loosening of bed does not occur.

By the results of the control it was found that at $P_{\mathrm{n}}=11 \mathrm{MPa}$, the active process of hydro impulsive loosening starts at a backup pressure in the well is about $1.5 \mathrm{MPa}$. The most intense cracking in the bed occurs at the backup pressure from 3.0 $\mathrm{MPa}$ to $6.0 \mathrm{MPa}$ within 5-6 minutes, while its maximum was $7.5 \mathrm{MPa}$. After that, the backup pressure sharply decreased to $2.0 \mathrm{MPa}$, and then, after 20-30 seconds, to about $0.8 \mathrm{MPa}$.

The analysis of the results of the monitoring of the backup pressure of the liquid in the well and the sound accompaniment spectrum of the hydro-impulsive loosening (see Fig. 1) are allowed to establish the following:

1. The active stage of hydro impulsive loosening of the bed occurs within 6-7 minutes at the backup pressure of the liquid in the well from 1.2 $\mathrm{MPa}$ to $7.5 \mathrm{MPa}$. The frequency response of the generator in this range is from $1.5 \mathrm{kHz}$ to $6.3 \mathrm{kHz}$;

2. The range of the AF spectrum of the signal generator operation $\mathrm{AE}$ is from $1.4 \mathrm{kHz}$ to $2.8 \mathrm{kHz}$. The most effective stage corresponds to the frequency of $1.6-2.4 \mathrm{kHz}$, and the maximum values of the energy level $f \approx 2.0 \mathrm{kHz}$.

\section{The method of calculating the generator efficiency}

The useful energy that realized under hydro-impulsive action consists of static and dynamic components. Following the works [12], the total energy flow $E$ is determined by the expression

$$
E=P_{\mathrm{p}} Q_{\mathrm{n}}+\Delta P \Delta Q
$$

where $P_{\mathrm{p}} Q_{\mathrm{n}}=E_{\mathrm{S}}$ is the energy flow corresponding to a steady flow, not associated with oscillations. It is determined by the backup pressure $P_{\mathrm{p}}$ and flow rate through the pump $Q_{\mathrm{n}}$. The second term in equation (1) is determined by the oscillatory components of pressure $\Delta P$ and flow rate $\Delta Q$ and called the flow of vibrational energy.

Oscillatory component $\Delta Q$ is determined from the condition of the balance of its equality of the detached part of the settled cavitation cavity $\Delta V_{\mathrm{c}}$ multiplied by oscillation frequency $f$

$$
\Delta Q=\Delta V_{\mathrm{c}} f
$$

The frequency of self-oscillations $f$ is determined by the formula [13]

$$
f=S h_{\mathrm{e}} \frac{v_{\mathrm{cr}}}{r_{\mathrm{cr}}} \tau,
$$

where $S h_{\mathrm{e}}-$ Strouhal number, whose approximation equation is determined on the basis of experimental data $S h_{\mathrm{e}}=0.0066 r_{\text {cr }}+0.0749$ with certainty $R^{2}=0.99 ; \tau, r_{\text {сr }}$ и $v_{\text {cr }}-$ the cavitation parameter, the radius of the generator's critical section, and the fluid velocity were determined by known formulas.

The amplitudes of the self-oscillations of the volume $\Delta V_{\mathrm{K}}$ were determined from the condition of the maximum volume of the settled cavitation cavity at the moment of its separation at $\ell_{\mathrm{c}} \leq \ell_{\mathrm{d}}$ (where $\ell_{\mathrm{c}}$ and $\ell_{\mathrm{d}}-$ axial lengths of the cavern and generator diffuser)

$$
\Delta V_{\mathrm{c}}=\frac{\pi \ell_{\mathrm{c}}}{2}\left[3 r_{\mathrm{cr}}^{2}(1-\mu)+3 r_{\mathrm{cr}} \ell_{\mathrm{c}}\left(\operatorname{tg} \frac{\beta}{2}-\operatorname{tg} \frac{\alpha}{2}\right)+\ell_{\mathrm{c}}^{2}\left(\operatorname{tg}^{2} \frac{\beta}{2}-\operatorname{tg}^{2} \frac{\alpha}{2}\right)\right] \text {, }
$$


where $\beta$ - expansion angle of the generator diffuser, $\alpha$ - the angle of expansion of the fluid jet, $\mu$-generator flow rate coefficient equal to 0.95 .

The axial length of the cavity depending on the degree of development of cavitation is determined in accordance with [14] by the formula

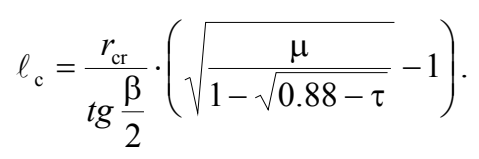

Thus, the calculation of the total energy flow $E$ (1) is made taking into account the oscillatory components of the flow rate $\Delta Q$ according to the formula (2) taking into account (3)-(5), and the pressure $P$ - according to the refined linear mathematical model of the cavitation generator [15].

Calculated energy fluxes are obtained at discharge pressures $P_{\mathrm{n}}=11 \mathrm{MPa}$, expansion angle of the generator diffuser $\beta=20^{\circ}$ and jet extensions $\alpha=1.35^{\circ}$, sound velocity in fluid $c=1100 \mathrm{~m} / \mathrm{s}$, flow rate coefficient $\mu=0.95$ and saturated vapor pressure $P_{\mathrm{s}}=0.0024 \mathrm{MPa}$.

\section{Analysis of the results}

Calculated dependencies of oscillatory components of pressure $\Delta P$, flow rate $\Delta Q$ and frequency $f$ from backup pressure $P_{\mathrm{n}}$ in the range of its change from 0.5 to $9 \mathrm{MPa}$ are presented on Figure 2.

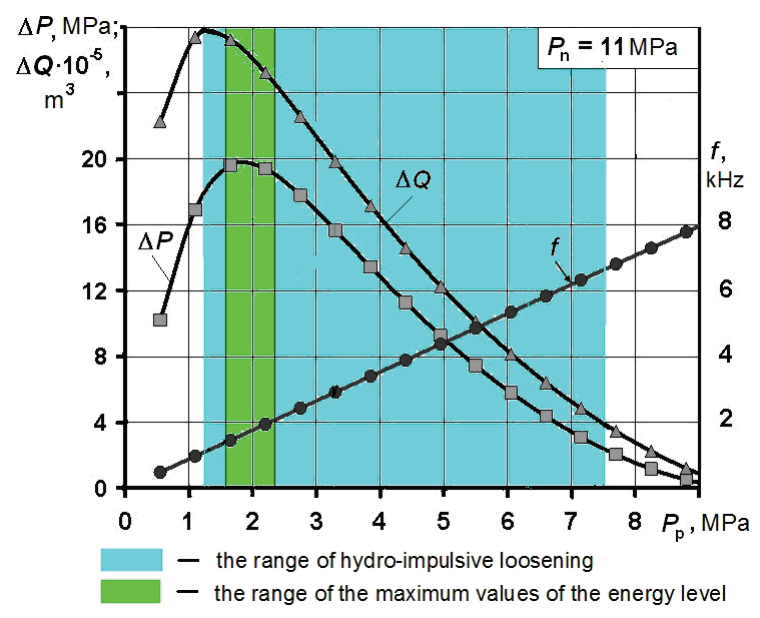

Fig. 2. Calculated dependencies of oscillatory components $\Delta P, \Delta Q$ and frequency $f$ from backup pressure of the liquid in the well $P_{\mathrm{n}}$.

The figure also shows the established range of the active stage of hydro-loosening at the pressure of the liquid in the well from 1.2 $\mathrm{MPa}$ to $7.5 \mathrm{MPa}$ and the $\mathrm{AF}$ zone of the $\mathrm{AE}$ signal at the most effective stage of the generator operation $1.6-2.4 \mathrm{kHz}$.

From the above results it can be seen that the range of the AF spectrum of the AE signal of the most effective stage of the generator operation $(1.6-2.4 \mathrm{kHz})$ corresponds to the backup pressure in the well from 1.2 to $3 \mathrm{MPa}$.

The analysis of the established dependencies $\Delta P=f\left(P_{\mathrm{p}}\right)$ and $\Delta Q=f\left(P_{\mathrm{p}}\right)$ shows that with growth of $P_{\mathrm{p}}$ values of oscillatory components $\Delta P, \Delta Q$ increases dramatically and, at certain values of $P_{\mathrm{p}} \approx 1.8$ and $P_{\mathrm{p}} \approx 1.3 \mathrm{MPa}$ respectively, reach their maximum. The maximum value of $\Delta P$ approximately 1.9 times exceeds the pressure at the inlet to the 
generator $P_{\mathrm{n}}$. Further, with an increase in the backup pressure of the liquid in the well, it is observed decreasing of their values to almost zero.

The calculations allowed us to determine the energy flux, which corresponds to oscillatory components $E_{\mathrm{o}}=\Delta P \cdot \Delta Q$, and the total energy flux $E$ (Fig. 3).

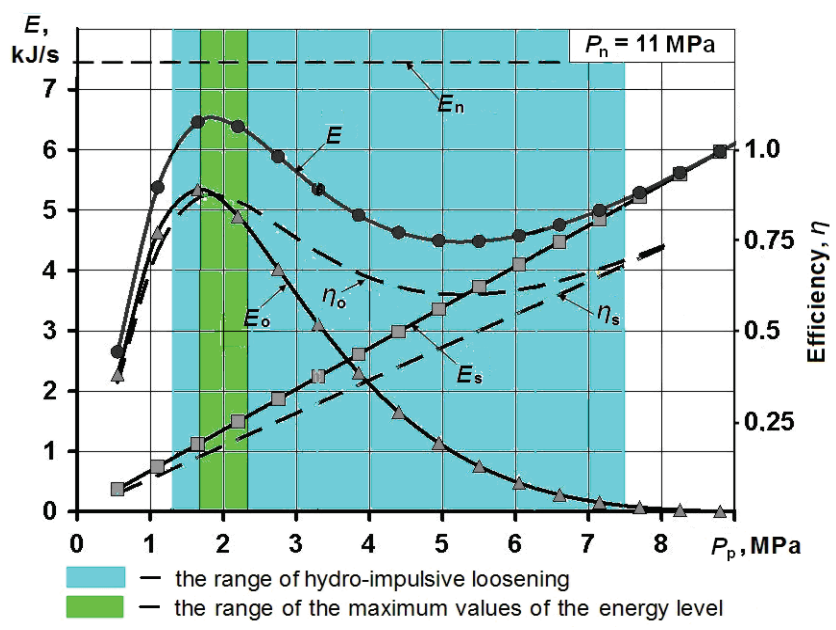

Fig. 3. Calculated dependences of energy fluxes and efficiency on the backup pressure $P_{\mathrm{p}}$.

From the established dependencies it is follows:

1. Relation $E_{\mathrm{s}}=f\left(P_{\mathrm{p}}\right)$ under the steady flow of liquid, is linear. Values $E_{\mathrm{s}}$ with the increasing of backup pressure increase and tend to the maximum value that is developed by the pump $E_{\mathrm{n}}$.

2. Under hydro impulsive action, when the backup pressure $P_{\mathrm{p}}$ varies from 0 to $\approx 1.5 \mathrm{MPa}$, the dynamic component $E_{\mathrm{o}}$ of the energy flux increases from zero to the maximum value $E_{\mathrm{o}} \approx 5.4 \mathrm{~kJ} / \mathrm{s}$. Further, wilth increasing of the backup pressure, the value of the dynamic component $E_{\mathrm{o}}$ monotonously decreases, reaching zero at $P_{\mathrm{p}} \approx 8.5 \mathrm{MPa}$. This is due to decreasing in the level of pressure fluctuations $\Delta P$ and volume flow rate $\Delta Q$ under increasing the backup pressure $P_{\mathrm{p}}$;

3. With an increasing of the backup pressure value $P_{\mathrm{p}}$ from zero to $\approx 1.7 \mathrm{MPa}$, the total energy flux $E$ increases under hydrodynamic action, reaching a maximum value of $E_{\max } \approx$ $6.5 \mathrm{~kJ} / \mathrm{s}$, with its subsequent decreasing. When $P_{\mathrm{p}} \approx 5.5 \mathrm{MPa}$, the total flux $E$ reaches the minimum value $\approx 4.5 \mathrm{~kJ} / \mathrm{s}$. A further increasing of the value of $E$ is explained by an increase in the component of the energy flux corresponding to the steady-state flow $E_{0}$, under a significant decreasing of the level of dynamic effects on the liquid.

The analysis of the obtained results allows to estimate the efficiency of hydro loosening under the pulsed or static injection of fluid into the coal bed.

The expression for efficiency under impulse action is represented as

$$
\eta_{\mathrm{o}}=\frac{E}{E_{\mathrm{n}}},
$$

and under the static injection

$$
\eta_{\mathrm{s}}=\frac{E_{\mathrm{s}}}{E_{\mathrm{n}}}
$$

Consideration of the calculated dependencies of efficiency under pulsed and static effects on the bed on the backup pressure $P_{\mathrm{p}}$ (see Fig. 3) shows that with increasing of 
backup pressure $P_{\mathrm{p}}$ from $0.5 \mathrm{MPa}$ the efficiency $\eta_{\mathrm{o}}$ first increases sharply, reaching a maximum value of 0.87 at $P_{\mathrm{p}} \approx 1.9 \mathrm{MPa}$, and, further, decreases to 0.6 at $P_{\mathrm{p}} \approx 5.5 \mathrm{MPa}$.

This behavior of $\eta_{\mathrm{o}}=f\left(P_{\mathrm{p}}\right)$ is caused by the nature of the dependence of $E$ on $P_{\mathrm{p}}$ (Fig. 3). A further increasing of efficiency $\eta_{\mathrm{o}}$ at $P_{\mathrm{p}}>5.5 \mathrm{MPa}$ is explained by the significant domination of the energy flux corresponding to the steady-state flow over the oscillatory component, which practically acquires a zero value at $P_{\mathrm{p}} \approx 8.5 \mathrm{MPa}$.

Comparison of dependencies $\eta_{\mathrm{o}}=f\left(P_{\mathrm{p}}\right)$ and $\eta_{\mathrm{s}}=f\left(P_{\mathrm{p}}\right)$ shows that in the range of backup pressure $P_{\mathrm{p}}$ variation from $0.5 \mathrm{MPa}$ to $6 \mathrm{MPa}$, the impulse effect on the coal bed is much more effective than the static injection.

\section{Conclusions}

Analysis of the results of mining and experimental studies made it possible to establish the working frequencies range of the device for the hydro impulsive effect on the coal bed. By calculation for the established frequency range the energy fluxes are determined corresponding to the static and hydro impulsive injection of the liquid into the coal bed. It made it possible to establish that:

- ceteris paribus (in pressure of injection and in the range of backup pressure from 1 to $6 \mathrm{MPa}$ ) the efficiency of hydro impulsive action exceeds the efficiency of static action by about 4.8-1.2 times, which leads to decreasing in energy consumption by about $50 \%$;

- the proposed method for evaluating the effectiveness of the device for hydroimpulsive action on a coal bed is of practical importance. At the design stage of new or improved existing equipment it allows to evaluate the effectiveness of the operation of cavitation generators in the process of hydro impulsive action without additional experimental studies.

The authors of the article express their gratitude to the researchers of the Donetsk Research Institute for providing assistance in conducting research on the hydro impulsive action on the outburst coal beds.

\section{References}

1. Vasilyev, L.M., Zhulay, Yu.A., Zberovskiy, V.V., Moiseenko, P.J., Trochimets, N.J. (2007). Ustrojstvo dlya hidroimpulsnogo vozdejstviya na ugolnyj plast. Patent No A 200710209, Ukraine

2. Y. Wonjae, A.Kyubok, An Experimental Study on Flow Characteristics of Cavitation Venturi. Journal of the Korean Society of Propulsion Engineers, 4, 19, 1-7 (2014)

3. A. Abedini, A. Ashrafizade, H. Karimi, M. Madandar. Experimental Performance Evaluation of a Cavitating Venturi. Arab J Sci Eng, 39, 1375-1380 (2014)

4. Lodus, E.V., Romanovskiy, S.L. (1976). Vliyanie skorosti deformirovaniya na prochnost i hrupkost udaroopasnyih ugley i kamennoy soli. Sbornyk nauchnkh trudov. VNII gornoy geomehaniki i marksheyderskogo dela, 99, 151-154

5. Pavlyish, V.N., Grebenkin, S.S. (2006). Fiziko-tehnicheskie osnovyi protsessov gidravlicheskogo vozdeystviya na ugolnyie plastyi: Donetsk: VIK

6. Kuznetsov, Yu.V., Torskiy, P.N. (1965). Sposob predvaritelnogo ryihleniya $i$ uvlazhneniya krepkih ugolnyih plastov. Patent No 174586, USSR

7. Poturaev, V.N., Mineev, S.P. (1992). Ispolzovanie vibratsionnyih i volnovyih udarnikov pri otrabotke vyibrosoopasnyih plastov. Kyiv: Naukova dumka

8. Mining rule in seams prone to gas-dynamic phenomena. (2005). [Standard Coal Ministry of Ukraine SIU 10.1.001740088], Coal Ministry of Ukraine

9. Zberovskyi, V.V., Zhulay, Yu.O., Vasylyev, D.L., Nykyforov, O.V., Kolchyn, H.Y., 
Anhelovskyi, O.A., Chuhunkov, I.F., Niskevych, O.M. (2012). Sposib hidroimpulsnoho rozpushuvannia vuhilnykh plastiv. Patent No u201201719, Ukraine

10. Deglin, B.M., Melkonyan, A.A. (2008). Zvukoulavlivayuschaya apparatura novogo pokoleniya «ZUA-98-06». Gornyiy informatsionno-analiticheskiy byulleten, (10), 260262

11. Zberovskiy, V.V. (2017). Otsenka effektivnosti gidroimpulsnogo vozdeystviya na ugolnyiy plast metodami akusticheskogo kontrolya. GeotehnIchna mehanIka, (132), 74-84

12. Raushenbah, B.V. (1961). Vibratsionnoe gorenie. Moskva: Fizmatgiz

13. Pilipenko, V.V., Manko, I.K., Zadontsev V.A. (1998). Cavitation self-oscillations intensify technological processes Proceedings of a Fluid Dynamics Panel Workshop. Kyiv. Ukraine. Report 827

14. Zhulaj, Yu.A., Voroshilov A.S., Komarov, S.V. (2015). Razrabotka raschetnojeksperimental'nogo metoda opredelenija chastot kavitacionnyh kolebanij. Zbirnyk naukovykh prats $N G U, 48,140-146$

15. Zhulaj, Yu.A. (2014). Utochnenie linejnoj matematicheskoj modeli kavitacionnogo generatora kolebanij davlenija zhidkosti. Aviacionno-kosmicheskaja tehnika $i$ tehnologija, 7 (114), 21-26 